\title{
DO WEBSITE QUALITY, FASHION CONSCIOUSNESS, AND SALES PROMOTION INCREASE IMPULSE BUYING BEHAVIOR OF E-COMMERCE BUYERS?
}

\author{
Allysha Tiffany Wiranata*) and Arga Hananto**)1 \\ *) International Undergraduate Class, Faculty of Economics and Business, Universitas Indonesia \\ Jl. Prof. Dr. Sumitro Djojohadikusumo, UI Depok 16424 \\ ${ }^{* *}$ Department of Management, Faculty of Economics and Business, Universitas Indonesia \\ Jl. Prof. Dr. Sumitro Djojohadikusumo, UI Depok 16424
}

\begin{abstract}
The prevalence of online shopping also gave rise to irrational shopping behavior like impulse buying, which makes up a large share of e-retailer revenue. This study's objective was to analyze the factors that affect impulse buying (i.e., website quality, sales promotion, and fashion consciousness) within the context of apparel/fashion product purchase. Besides, this study also sought to examine the role of sales promotion in moderating the relationship between website quality and impulse buying. An online survey with a final sample size of 211 respondents was carried out using Google Forms and analyzed with Confirmatory Factor Analysis and multiple regression analysis (using R Statistical Software) to analyze four hypotheses. The result indicated that website quality did not affect impulse buying, while sales promotion and fashion consciousness was found to affect impulse buying positively. However, the role of website quality was still critical, since it still played a role as a hygiene factor. Once website quality interacted with sales promotion, it could positively affect impulse buying.
\end{abstract}

Keywords: fashion consciousness, impulse buying, sales promotion, website quality

\begin{abstract}
Abstrak: Meningkatnya belanja on-line juga meningkatkan timbulnya perilaku belanja tidak rasional seperti pembelian secara impuls, yang memberikan kontribusi besar terhadap pelaku e-commerce. Penelitian ini bertujuan untuk menganalisis faktor-faktor yang mempengaruhi pembelian secara impuls (yaitu kualitas situs web, promosi penjualan, dan kesadaran fashion) dengan menggunakan konteks pembelian produk pakaian/fashion. Selain itu, penelitian ini juga bertujuan menganalisis pengaruh promosi penjualan dalam memoderasi hubungan antara kualitas situs web dan pembelian secara impuls. Survei daring dilakukan dengan menggunakan Google Forms. Survei ini menghasilkan sampel akhir dengan jumlah sebanyak 211 responden. Data dianalisis dengan Confirmatory Factor Analysis dan analisis regresi berganda (dengan $R$ Statistical Software) untuk menganalisis empat hipotesis. Hasil penelitian ini menunjukkan bahwa kualitas situs web tidak berpengaruh terhadap pembelian secara impuls, sementara promosi penjualan dan kesadaran fashion berpengaruh positifterhadap pembelian secara impuls. Walapun begitu, peran kualitas situs web tetaplah penting, sebab kualitas situs web berperan sebagai faktor hygiene dan apabila kualitas situs web berinteraksi dengan promosi penjualan, maka interaksi kedua variabel tersebut dapat berpengaruh positif terhadap pembelian secara impuls.
\end{abstract}

Kata kunci: kesadaran fashion, kualitas website, pembelian impuls, promosi penjualan

${ }^{1}$ Corresponding author:

Email: arga.hananto@ui.ac.id 


\section{INTRODUCTION}

The pervasive use of the internet has also shifted the retailing landscape. According to Euromonitor International (2018), Indonesia has experienced fast e-commerce growth that will significantly shift shopping habits. For instance, Euromonitor International reported that overall value of Indonesia's internet retailing has shifted from IDR 8.2 trillion in 2012 to IDR 46.5 trillion in 2017, with media products, consumer electronics, and apparel and footwear being the top three categories with the highest sales value.

Online purchasing has started to become the consumer's more preferred alternative to having to go to a store and spend time commuting to and from the store (Prihantoro et al. 2018). The shift toward internet retailing also means that consumer behavior research must also be aimed at how consumers react to stimuli in e-commerce setting. Online impulse buying behavior is an integral aspect of e-commerce, as there is increasing competition between e-commerce companies. They need to work harder to attract consumers to shop at their sites, often by creating impulsiveness through manipulating various marketing and environmental stimuli. Liu et al. (2013) found that internet shoppers were found to be more impulsive than non-internet-shoppers, indicating that impulse buying behavior is evident in e-commerce setting. Lo et al. (2016) suggested that online shopping reflected rational and irrational behavior (i.e., impulse buying behavior), and in particular, irrational behavior made up a large share of e-retailer revenue. This makes inducement of impulse buying behavior a desirable strategy for e-retailers.

According to Rook (1987), "Impulse buying occurs when a consumer experiences a sudden, often powerful and persistent urge to buy something immediately". Madhavaram and Laverie (2004) suggested that impulse buying followed an exposure to an often hedonically charged external stimuli, and this stimuli were not limited to just the product. Lo et al.(2016) suggested that impulse buying in online setting was a manifestation of consumer's inability to control shopping impulses when he/she encountered consumptive stimuli. Concluding from past studies, Leong et al. (2018) suggested that impulse buying was performed spontaneously and charged with positive emotion, lack of consideration for cost or consequences, and induced by hedonic temptation to seek instant gratification by consumption.
Bellini et al. (2017) reported that past studies suggested that individual characteristics (demographical characteristics and personality traits), product category, and situational factors were three main antecedents to impulse buying. Younger people with certain personality characteristics, such as having high shopping tendency would tend to engage in impulse buying. Bellini et al. (2017) also suggested that the more hedonic the product category, the more likely a person would make impulse buying.

Akram et al. (2017) used stimulus-organism-response (S-O-R) structure to study online impulse buying. They suggested that this mechanism could be used to study online impulse buying since many past studies have examined the interactions between environmental cues, consumers' affective and cognitive conditions, and the resulting behaviors. Chen et al. (2016) suggested that based on the latent state-trait (LST) theory, environmental states or cues, individual factors or traits, and the interactions between these two determinants could affect human behaviors.

Past research has suggested that website attributes or design was an environmental cue that can contribute toward influencing impulsive buying behavior. Website design factors, such as perceived usefulness and ease of use have become frequently cited variables of interest when studying applications (Prihantoro et al. 2018). Turkyilmaz et al. (2015) found that website design factors like usefulness, ease of use, and entertainment affected consumers' online buying impulsiveness. Wells et al. (2011) suggested that website quality (security, functional convenience, and visual appeal) significantly affected the urge to buy impulsively. Floh and Madlberger (2013) found that e-store atmospheric cues (e-store content, design, and navigation) indirectly affected impulse buying behavior through shopping enjoyment. Lo et al. (2016) suggested that the design elements of online stores were part of hygiene factors that affected online impulse buying behavior, while sales promotion stimuli comprised the motivation factor that effectively induced impulse buying.

According to Solomon et al. (2018), sales promotion was designed to stimulate immediate purchase and trial of a product during a certain period, thus very likely to trigger impulse buying behavior. According to Dholakia's consumption impulse enactment model, sales promotion is part of external stimuli that if present 
on e-commerce websites to an adequate level, could form consumption impulse (Dawson and Kim, 2009). In line with Dawson and Kim (2009), Badgaiyan and Verma (2015) proposed that sales promotion was part of situational factor that could stimulate impulsive buying behavior. Lo et al. (2016) summarized past research and suggested that sales promotion stimuli could evoke impulse buying by implying immediate reward that if it was forgone, it might make the consumer to feel regret over a missed opportunity, thus would trigger the consumer to engage in impulse buying to avoid missing out the opportunity.

Fashion consciousness or fashion involvement, refered to the desire to follow and adopt an up-to-date styles to sustain a person's status in a social network (Lertwannawit and Mandhachitara, 2012). Past studies concerning apparel or clothing have included fashion consciousness as an independent variable. According to O'Cass et al. (2013), a fashion-conscious consumer tended to be highly involved with all things regarding fashion, and these consumers were more likely to be involved in shopping activities compared to their less fashion conscious peers. Park et al. (2006) summarized past studies that suggested that fashion involvement provided sensory or experiential cues of various fashion products, such that the person with high fashion involvement who saw a new fashion product that fit his/her preference would be more likely to buy it immediately. Study by Eriksson et al. (2017) suggested that fashion consciousness was positively related to the frequency of browsing and purchasing clothing on-line through mobile phone. Also, they indicated that impulsiveness was positively related to browsing and purchasing clothing with a smartphone.

This study was carried out to investigate the factors underlying impulse buying behavior in an online context. Specifically, this research would like to analyze how website quality, sales promotion, and fashion consciousness affect impulse buying behavior. In addition, the authors would like to analyze the moderating role of sales promotion and fashion consciousness in the relationship between website quality and impulse buying behavior. This study would be carried out within the context of impulse buying behavior of the apparel/ fashion product category in Indonesia's e-commerce industry. The authors selected apparel/fashion since it tends to display more prevalent cases of impulsive buying behavior due to its nature of being a sensory and experiential product. For instance, Liao et al. (2009) reported clothing items as one of the most likely items to buy impulsively. Later research by Kim (2008) in Park et al. 2012) indicated that impulse buying tendencies tended to dominate online purchase of sensory products such as clothing, accessories, and jewelry. Apparently, this might happened because apparel represented experiential product with strong symbolic meaning that might be associated with many types of hedonic consumer behavior, like browsing or impulse buying (Park et al., 2012).

Several contributions may be created from this study. Firstly, the study may contribute toward understanding the factors that affect impulse buying behavior toward fashion product in the context of Indonesia's e-commerce. Badgaiyan and Verma (2015) suggested that impulse buying was an important retail sales driver, and Indonesia's e-commerce is a rapidly growing. Over 90 percent of Indonesia's internet users have already used e-commerce to buy goods and services (Kemp and Moey, 2019), with fashion/apparel products were reported among the top 3 most popular products in Indonesia's e-commerce applications/websites. By understanding the factors that affect impulse buying in this rapidly growing sector can aid the marketers of fashion products and e-commerce firms to craft an effective marketing strategy that can increase sales revenue and growth. Secondly, the study may contribute insights on online impulse buying within the Indonesian context, a market with a retail sales value of over USD 154 billion in 2018 (Euromonitor International, 2019). Thus adding a country-specific insights to complement existing repository of impulse buying studies that was previously conducted in western countries, as well as India and China (Akram et al. 2017; Badgaiyan and Verma, 2015).

\section{METHODS}

Primary data were used and collected through an online survey using Google Forms. The link to request survey participation was distributed through the first author's social media and online messaging applications. Sampling was carried out using convenience sampling technique with the following criteria: aged between 1844 , currently living in the Jakarta area, and have made an unplanned purchase of fashion items using a website in the past two months (verified with a screening question that included definition of impulsive buying). Convenience sampling had to be used due to lack of sampling frame required for random sampling. 
Data collection resulted in a total of 273 responses, which was then checked for completeness and compliance to respondent criteria. As a result, the authors gained 211 qualified responses. The number of responses was deemed sufficient, since it exceeds the minimum sample size rule of five observations per variable (in this case was 23 observed variables x $5=115$ respondents) as recommended by Hair et al. (2014).

This research measured 23 observed variables, which represented six constructs (usefulness, ease of use, entertainment, sales promotion, fashion consciousness, and impulsive buying behavior) comprising the research model as depicted in Figure 1, all measured with 7-point Likert scale. It is worth noting that the seventh construct (website quality) is a second-order construct reflected by usefulness, ease of use, and entertainment. The measurement items for impulse buying were taken from Rook and Fisher (1995). Website quality's first order constructs (usefulness, ease of use, and entertainment) were taken from Turkyilmaz et al. (2015), sales promotion was taken from Badgaiyan and Verma (2015), and fashion consciousness was taken from Sproles and Kendall (1986). Questionnaire was administered in Bahasa Indonesia, and back to back translation was carried out by the second author. The pre-test was carried out on 30 respondents recruited by convenience sampling. The pre-test data of 30 initial respondents indicated that all constructs exceeded minimum Cronbach's alpha threshold of 0.7 as suggested by Nunnally (1978). Thus all measurements could be used in the main survey.

Four hypotheses were formulated based on the past literatures, primarily based on the work of Akram et al. (2017) and Badgaiyan and Verma (2015). The hypotheses and the argumentation underlying each hypothesis are as follows:

Just as offline retailers could manipulate store environment to stimulate impulse purchase, various website characteristics that represent website quality served as environment cues that influenced impulsive buying (Wells et al. 2011). Past research suggested that website's ease of use, usefulness, and ability to entertain have been cited in several literatures as factors that could affect impulse buying behavior either directly or indirectly (e.g., Chen and Yao, 2018; Liu et al. 2013; Parboteeah et al. 2009; Turkyilmaz et al. 2015). Available literature has suggested that website quality attributes could affect impulse buying behavior by invoking some positive emotional response that made impulse buying behavior more likely to happen (Liu et al. 2013).

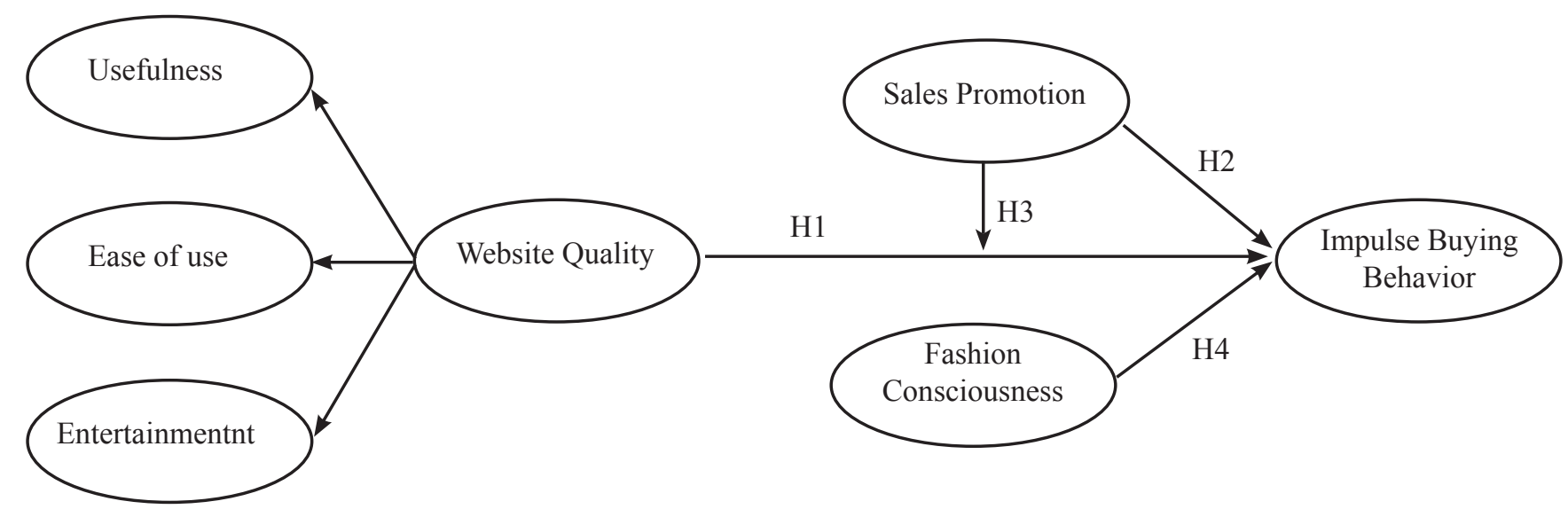

Figure 1. Reseach framework 
H1: Website quality has a positive and significant impact on impulse buying behavior

External marketing cues, such as sales promotion could encourage impulse purchases (Dawson and Kim, 2009). A recent study by Sundström et al. (2019) also suggested that some forms of sales promotion, such as free shipping, sale, or low price for a limited time could trigger impulse buying. The price-based promotion seemed to be driving the consumers to visit the e-commerce site offering the promoted items, and subsequently entice the consumer to make the purchase (Sundström et al. 2019). Mittal et al. (2018) suggested that sales promotion encouraged browsing to the extent that someone might make a special effort to visit the store that offered the sales promotion, and subsequently engage in impulse buying since, perception of higher value for money helped justify the impulse buying. Chen and Yao (2018) suggested that sales promotion made consumers yield to impulse buying since it increased positive emotion and changed the consumer's standard of reference price, which subsequently affected their willingness to make a purchase. Lo et al. (2016) proposed that website quality elements might be considered as hygiene factor (i.e., the basic conditions to prevent users from leaving an online store, but not enough to stimulate impulse buying), while sales promotion was listed as a motivator of online impulse buying. This might indicate that sales promotion might strengthen an e-commerce website/platform's influence in inducing impulse buying

The authors would argue that based on the past studies regarding website quality and sales promotion, the existence of sales promotion would increase the positive affect already aroused by good website quality attributes, and subsequently increase consumer's impulse buying behavior.

H2: Sales promotion has a positive and significant impact on impulse buying behavior

H3: Sales promotion positively moderates the relationship between website quality and impulse buying behavior

Fashion-conscious consumers would be highly involved with fashion, like to keep abreast of the latest fashion, and place a high importance of the latest fashionable and attractive styling (O'Cass et al. 2013). Thus they would tend to seek new fashion items by visiting stores (offline and online) with excitement and pleasure. As stated in impulse buying literatures, theurge to buy impulsively (which is precursor to impulse buying), might be felt upon encountering an object in the environment (Leong et al. 2018). Therefore, the authors suggested that fashion-conscious individuals to be more prone to perform impulse buying since they would be more motivated to visit e-commerce sites to explore fashion items, and when they encounter the fashion items, they would likely to engage in impulse buying.

H4: Fashion consciousness has a positive and significant impact on impulse buying behavior

The data were analyzed with covariance-based confirmatory factor analysis (CFA) using Lavaan package (Roseel 2012), followed by moderated multiple regression analysis in R Statistical Program (R Core Team 2013). Lavaan (latent variable analysis) provides a collection of tools to explore, estimate, and understand various latent variable models, such as factor analysis, structural equation, longitudinal, multilevel, latent class, item response, and missing data models (Roseel, 2012).

In this study, the authors applied Lavaan to fit the CFA model from continuous observed variables. The use of CFA was required to generate latent variable score for website quality construct, which was a second order construct comprised of usefulness, ease of use, and entertainment. In addition, the use of CFA might be justified since the constructs in this study consisted of latent variables measured by multiple observed variables. Computing a model in Lavaan required two steps: specifying the model (confirmatory factor analysis) and carry out the analysis (Beaujean, 2014). Lavaan is relatively easy to use and accepts either covariance matrix or raw data as input, as well as having the same parameter estimation techniques, such as maximum likelihood as typically used in commercial SEM software, such as LISREL or AMOS. Upon completion of CFA using Lavaan, the authors would use the CFA result as an input for the multiple regression analysis, also carried out in $\mathrm{R}$ using multiple regression analysis function provided in its base package. 


\section{RESULTS}

\section{Respondents Profile}

The data from 211 valid responses were analyzed. All respondents resided in the Jakarta area. The authors conducted descriptive analysis to get the respondent profile (see Table 1) followed by CFA and multiple regression analysis. From Table 1, most respondents were females. In addition, respondents were mostly aged between 18 and 26 years old, and mostly had occupation as students and employees.

\section{Reliability and Validity Analysis}

After the final data collection was completed, the measurement items were checked for reliability using Cronbach's alpha and Construct Reliability (CR). The authors also analyzed the convergent validity (by examining Average Variance Extracted and item loadings) as well as discriminant validity based on Fornell -Larcker criterion (Fornell and Larcker, 1981). In terms of reliability, from Table 2, all constructs exhibited Cronbach's alpha values above 0.7, as suggested by Nunnally (1978), as well as CR higher than 0.7, as suggested in Hair et al. (2014). Meanwhile, the measurement items also passed the minimum requirement for convergent validity since all constructs demonstrated AVE $>0.5$ and item loadings higher than 0.5, as suggested in Hair et al. (2014). To check discriminant validity, based on Fornell and Larcker (1981), the authors compared the square-root of AVE (placed on the diagonals of Table 3 ) and the correlation between constructs (figures off the diagonals in Table 3). As seen in Table 3, all diagonal figures (square-root of AVE of each construct) were higher than the offdiagonal values, thus established discriminant validity. CFA model fit figures can be found in Table 4. From Table 4, it can be seen that all absolute fit measures, incremental fit measures, and parsimonious fit measures fulfilled the suggested threshold suggested in Hair et al. (2014) and Bagozzi and Yi (1988). Thus, establishing a good fit for the CFA model.

As the next step in the analysis, the authors saved factor score from the CFA analysis and used it as data for multiple regression analysis. Multiple regression analysis was carried out to analyze the effect of website quality, sales promotion, and fashion consciousness, as well as sales promotion as a moderating variable.
The means and standard deviation of each construct are reported in Table 2. Impulse buying behavior $(\mathrm{M}=4.462, \mathrm{SD}=1.306)$ indicated a modest level of impulse buying behavior reported by the respondents. However, noting the standard deviation variable value, we can conclude that the respondents indicated varying level of impulse buying behavior.

Overall, all website quality dimensions were rated relatively high. In terms of perceived usefulness $(\mathrm{M}=$ $5.526, \mathrm{SD}=1.036$ ), on average, the respondents agreed that the e-commerce websites they used had a relatively high usefulness level. Similarly, in terms of ease of use $(\mathrm{M}=5.970, \mathrm{SD}=0.837)$ and entertainment $(\mathrm{M}=5.347$, $\mathrm{SD}=1.043)$, respondents agreed that, on average, the e-commerce websites they used were easy to use and can be considered entertaining.

Table 1. Respondent profile

\begin{tabular}{lc}
\hline & Percentage \\
\hline Gender & \\
Females & $77 \%$ \\
Males & $23 \%$ \\
& \\
Age & \\
$18-26$ & $77 \%$ \\
$27-35$ & $18 \%$ \\
$26-44$ & $5 \%$ \\
& \\
Monthly Expenditure & \\
$<$ Rp.1.000.000 & \\
Rp.1.000.000-4.000.000 & $17 \%$ \\
Rp.4.000.001-Rp.8.000.000 & $55 \%$ \\
$>$ Rp.8.000.001-12.000.000 & $20 \%$ \\
$>$ Rp.12.000.001 & $7 \%$ \\
& $1 \%$ \\
Highest degree attained & \\
Highschool & \\
Diploma & \\
Undergraduate & $34 \%$ \\
Postgraduate & $7 \%$ \\
Occupation & $48 \%$ \\
Student & $11 \%$ \\
Entrepreneur & \\
Employee & \\
Others & \\
\hline & \\
& \\
& \\
& \\
& \\
&
\end{tabular}


Table 2. Construct reliability and validity

\begin{tabular}{|c|c|c|c|c|c|c|c|}
\hline \multirow{2}{*}{ Constructs } & \multirow{2}{*}{ Mean } & \multirow{2}{*}{ SD } & \multirow{2}{*}{ Items } & \multirow{2}{*}{$\begin{array}{l}\text { Factor } \\
\text { loading }\end{array}$} & \multicolumn{2}{|c|}{ Reliability } & \multirow{2}{*}{$\frac{\text { Validity }}{\text { AVE }}$} \\
\hline & & & & & Cronbach's Alpha & $\mathrm{CR}$ & \\
\hline \multirow{4}{*}{$\begin{array}{l}\text { Impulse } \\
\text { buying } \\
\text { behavior (IB) }\end{array}$} & \multirow[t]{4}{*}{4.462} & \multirow[t]{4}{*}{1.306} & IB1 & 0.809 & \multirow[t]{4}{*}{0.85} & \multirow[t]{4}{*}{0.897} & \multirow[t]{4}{*}{0.596} \\
\hline & & & IB2 & 0.823 & & & \\
\hline & & & IB3 & 0.773 & & & \\
\hline & & & IB4 & 0.675 & & & \\
\hline \multirow{4}{*}{$\begin{array}{l}\text { Usefulness } \\
\text { (PU) }\end{array}$} & \multirow[t]{4}{*}{5.526} & \multirow[t]{4}{*}{1.036} & PU1 & 0.813 & \multirow[t]{4}{*}{0.91} & \multirow[t]{4}{*}{0.977} & \multirow[t]{4}{*}{0.715} \\
\hline & & & PU2 & 0.930 & & & \\
\hline & & & PU3 & 0.902 & & & \\
\hline & & & PU4 & 0.721 & & & \\
\hline \multirow{4}{*}{$\begin{array}{l}\text { Ease of use } \\
\text { (PEOU) }\end{array}$} & \multirow[t]{4}{*}{5.970} & \multirow[t]{4}{*}{0.837} & EU1 & 0.877 & \multirow[t]{4}{*}{0.93} & \multirow[t]{4}{*}{0.984} & \multirow[t]{4}{*}{0.766} \\
\hline & & & EU2 & 0.930 & & & \\
\hline & & & EU3 & 0.906 & & & \\
\hline & & & EU4 & 0.781 & & & \\
\hline \multirow{4}{*}{$\begin{array}{l}\text { Entertainment } \\
\text { (ENT) }\end{array}$} & \multirow[t]{4}{*}{5.347} & \multirow[t]{4}{*}{1.043} & EN1 & 0.754 & \multirow[t]{4}{*}{0.89} & \multirow[t]{4}{*}{0.974} & \multirow[t]{4}{*}{0.670} \\
\hline & & & EN2 & 0.793 & & & \\
\hline & & & EN3 & 0.880 & & & \\
\hline & & & EN4 & 0.843 & & & \\
\hline Sales & 5.423 & 1.246 & SP1 & 0.87 & 0.85 & 0.958 & 0.657 \\
\hline $\begin{array}{l}\text { promotion } \\
\text { (SP) }\end{array}$ & & & $\mathrm{SP} 2$ & 0.802 & & & \\
\hline & & & $\mathrm{SP} 3$ & 0.755 & & & \\
\hline Fashion & 5.233 & 0.969 & $\mathrm{FC} 1$ & 0.776 & 0.83 & 0.967 & 0.553 \\
\hline $\begin{array}{l}\text { consciousness } \\
\text { (FC) }\end{array}$ & & & $\mathrm{FC} 2$ & 0.83 & & & \\
\hline & & & FC3 & 0.742 & & & \\
\hline & & & $\mathrm{FC} 4$ & 0.608 & & & \\
\hline Website & $\mathrm{n} / \mathrm{a}$ & & Usefulness & 0.670 & $\mathrm{n} / \mathrm{a}$ & 0.899 & 0.519 \\
\hline Quality* & & & Ease of Use & 0.807 & & & \\
\hline & & & Entertainment & 0.677 & & & \\
\hline
\end{tabular}

*Second order construct consisting of usefulness, ease of use and entertainment

Table 3. Discriminant validity analysis

\begin{tabular}{|c|c|c|c|c|c|c|}
\hline & IB & $\mathrm{PU}$ & PEOU & ENT & SP & $\mathrm{FC}$ \\
\hline IB & 0.772 & & & & & \\
\hline PU & 0.230 & 0.845 & & & & \\
\hline PEOU & 0.194 & 0.564 & 0.875 & & & \\
\hline ENT & 0.203 & 0.418 & 0.543 & 0.819 & & \\
\hline SP & 0.555 & 0.270 & 0.282 & 0.248 & 0.810 & \\
\hline $\mathrm{FC}$ & 0.481 & 0.332 & 0.395 & 0.445 & 0.431 & 0.744 \\
\hline
\end{tabular}

Table 4. CFA model fit

\begin{tabular}{lcccll}
\hline \multicolumn{1}{c}{ Indexes } & & Suggested cut off & Actual & Result & \multicolumn{1}{c}{ Reference } \\
\hline Absolute fit measures & $\chi 2 / \mathrm{df}$ & $<3$ & 1.843 & Satisfied & Hair et al. (2014) \\
& GFI & $>0.8$ & 0.865 & Satisfied & Bagozzi and Yi (1988) \\
& AGFI & $>0.8$ & 0.831 & Satisfied & Bagozzi and Yi (1988) \\
Incremental fit measures & RMSEA & $<0.08$ & 0.063 & Satisfied & Hair et al. (2014) \\
& IFI & $>0.9$ & 0.942 & Satisfied & Bagozzi andYi, 1988; Hair et \\
& NNFI & $>0.9$ & 0.932 & Satisfied & al. (2014) \\
Parsimonious fit measures & CFI & $>0.9$ & 0.941 & Satisfied & \\
& PNFI & $>0.5$ & 0.769 & Satisfied & Hair et al. (2014) \\
\hline
\end{tabular}


The respondents also indicated agreement to the statements that measure their reaction to sales promotion offered in the e-commerce websites they visited. The construct's mean $(M=5.423, S D=1.246)$, suggested their tendency to react positively (i.e., stimulated to make unplanned or spontaneous purchase) if the e-commerce website offers sales promotion. Lastly, respondents reported a relatively high average value of fashion consciousness $(\mathrm{M}=5.233, \mathrm{SD}=0.969)$, suggested that these respondents (who happened to come from a relatively younger age group, being mostly aged 18-35) tended to be fashion conscious people.

Table 5 contains summary of multiple regression results. From the table, sales promotion (standardized $\beta$ $=0.484, \mathrm{t}=8.305, \mathrm{p}<0.001)$ and fashion consciousness (standardized $\beta=0.375, \mathrm{t}=5.585, \mathrm{p}<0.001$ ) were reported to have significant and positive association with impulse buying, with sales promotion was also found significant as moderating variable (standardized $\beta=0.141, \mathrm{t}=2.818, \mathrm{p}<0.01)$.

Based on the multiple regression analysis, the first hypothesis was not supported, since website quality was not found significant (standardized $\beta=-0.095, t=-.460$, $\mathrm{p}>0.1$ ). Contrary to past research (e.g., Chen and Yao 2018; Liu et al. 2013; Parboteeah et al. 2009; Turkyilmaz et al. 2015), apparently, in this study, website quality alone was not enough to stimulate impulse buying. This is contrary to Akram et al. (2017) and Turkyilmaz et al. (2015)'s findings. Website quality elements can probably be viewed through Herzberg's two-factor theory (Lo et al. 2016). According to Lo et al. (2016), website quality elements captured in constructs, such as website ease of use, usefulness, and entertainment were considered as hygiene factors (i.e., those that become necessary conditions during purchase, but do not necessarily trigger consumer's purchase impulses). Lo et al. (2016) added that these elements pertaining to website quality were consistently listed as hygiene factors by respondents across all stages of consumer decision-making process. Another perspective is offered by Liu et al. (2013), who explained that website quality elements, such as ease of use and visual appeal stimulated impulse buying behavior indirectly through invoking pleasure in interacting with the website, which in turn enhanced the felt gratification of online impulse buying.

While website quality did not affect impulse buying, sales promotion was found significant in affecting impulse buying. This is in line with findings from the past researches (e.g., Akram et al. 2017; Chen and Yao 2018; Mittal et al. 2018; Sundström et al. 2019) that proposed sales promotion could stimulate impulse buying. From two-factor theory perspective, Lo et al. (2016) found that most elements (e.g. buy one get one free, limited time sales, bonus reward) were related to sales promotion, while website quality elements were related to hygiene factor. This finding seems to support notion by Mittal et al. (2018) who suggested that the existence of sales promotion could instigate perception of higher value for money, which could justify the impulse buying, consequently encourage the consumer to engage in impulse buying.

Table 5. Summary of multiple regression analysis results

\begin{tabular}{lccccc}
\hline \multicolumn{1}{c}{ Variable } & $\mathrm{B}$ & Standard Error & & $\mathrm{t}$ & $\mathrm{V}$ \\
\hline (Intercept) & -0.068 & 0.055 & -1.230 & - & - \\
Website quality & -0.164 & 0.112 & -1.460 & -0.095 & 1.704 \\
Sales promotion & 0.441 & 0.053 & $8.305^{* * *}$ & 0.484 & 1.369 \\
Fashion consciousness & 0.422 & 0.076 & $5.585^{* * *}$ & 0.375 & 1.819 \\
Website quality x Sales promotion & 0.246 & 0.087 & $2.818^{* *}$ & 0.141 & 1.006 \\
\hline
\end{tabular}

$\mathrm{R}^{2}$ (adjusted) $=0.479 ; \mathrm{F}(4,206)=49.3 .18^{* * *}$

Dependent variable: Impulse buying;

*Significant at $\mathrm{p}<0.05 ; * *$ Significant at $\mathrm{p}<0.01$; ***Significant at $\mathrm{p}<0.001$; 
In line with Akram et al. (2018) and Badgaiyan and Verma (2015), sales promotion affected impulse buying as a moderating variable. From Table 4, the regression coefficient of interaction between website quality and sales promotion (standardized $\beta=0.141, \mathrm{t}$ $=2.818, \mathrm{p}<0.01$ ) was found significant with a positive slope. Figure 2 shows the graphical relationship between website quality and impulse buying with sales promotion as moderating variable. In Figure 2, under the low value of sales promotion, the slope of website quality was relatively flat, indicating low or no effect toward affecting impulse buying. In contrast, under the high value of sales promotion, the slope became steeper with a positive slope, thus indicating existence of positive interaction effect. This finding further strengthens the finding that website quality might serve as a hygiene factor, while existence of sales promotion would be required to capitalize on the positive website quality.

The last independent variable, fashion consciousness, was also found significant. Lertwannawit and Mandhachitara (2012) proposed that people who were fashion conscious tended to have the desire for and adoption of up-to-date styles so that they could maintain their status in their social network. This notion implies that fashion conscious people tended to keep up with the latest fashion, and subsequently, when encountering stimuli, they would be more prone to engage in impulse buying (Leong et al. 2018 and O'Cass et al. 2013).

\section{Managerial Implications}

The hypothesis testing suggested that website quality was not enough to stimulate impulse buying. This finding supports Lo et al.(2016) who suggested that factors pertaining to website quality were associated with hygiene factors. Lo et al.(2016) further suggested that these hygiene factors, if not fulfilled by e-commerce sites, might increase consumer's vigilance toward uncertain information. Therefore, thepersuasive power of the online store design or sales promotion messages might be reduced, and eventually inhibited online impulse buying. Thus, e-commerce firms must offer a good quality website/application, which is easy to read and understandd and create visually appealing and entertaining website/application design capable ofdelivering hedonic benefits.
Since this study indicated the significant role of sales promotion both as an independent variable as well as a moderating variable that moderates relationship between website quality and impulse buying behavior, e-commerce firms need to provide and manage sales promotion strategically. Lo et al. (2016) suggested that sales promotion might play an essential role during the pre-purchase evaluation of alternatives. Their study mentioned that some sales promotion tactics (buy one get one free, limited time sales, group buying promotional programs, bonus reward, and gifts) can be used to affect impulse buying, particularly during pre-purchase evaluation of alternatives. Types of sales promotion employed in e-commerce sites/platforms can be distinguished based on the types of customers (new and returning customers). Akram et al. (2018) suggested using monetary sales promotion to lure new customers, while returning customers may be enticed with non-monetary sales promotion (gifts, bonus, or contests and sweepstakes).

Another finding from this study is related to the role of consumer's personal factor (fashion consciousness) in affecting impulse buying of fashion products. The result suggested that e-commerce websites/platforms should align their marketing efforts with the consumers' interest or involvement with a product category, particularly fashion items which may carry profound personal relevance and perceived risk (e.g., risk of wearing out of season fashion). Besides, in the long term, e-commerce websites/platforms that sell fashion clothing can invest in various marketing communication activities to stimulate fashion consciousness of their future target markets, as well as to maintain the fashion consciousness of the existing target markets.

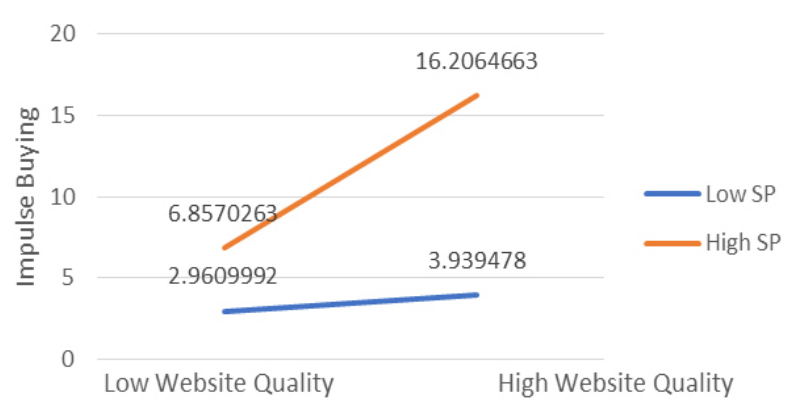

Figure 2. Moderation plot of sales promotion 
Combining the insights from the results of this study, the authors suggested that e-commerce websites/platforms need to combine good website quality characteristics with behavioral targeting, product recommendation, other cues related to fashion products, and sales promotion offerings to stimulate impulse buying. Since they tend to have higher involvement with fashion products, fashion-conscious customers would likely to pay attention to fashion products cues posted in the home page of the e-commerce website/platform. In addition, conspicuous sales promotion cues would likely to stimulate impulse buying, provided that the e-commerce websites/platforms demonstrate adequate website quality, which is considered as a hygiene factor (must have for an e-commerce websites/platforma).

\section{CONCLUSIONS AND RECOMMENDATION}

\section{Conclusions}

This study investigated the factors underlying impulse buying behavior in the online context. Literature has suggested that website quality, sales promotion, and fashion consciousness were three prominent factors that might affect impulse buying. Literature has also suggested dual function of sales promotion (i.e., as an independent variable as well as a moderating variable that moderates the relationship between website quality and impulse buying). Result from this study confirmed that sales promotion and fashion consciousness affected impulse buying.

This study could not find evidence that website quality directly affected impulse buying. Instead, the authors found that website quality seemed to serve as a hygiene factor that would require sales promotion to supplement the website's good quality design to stimulate impulse buying.

This study also found positive relationship between personal factor (i.e., fashion consciousness) and impulse buying behavior. Fashion-conscious people would tend to engage in impulse buying of fashion products, since they already have higher than average interest toward fashion products, thus making them more susceptible to impulse buying urge.

\section{Recommendations}

This study encountered sample size limitation. This study had a sample size of 211 respondents, and most of them $(77 \%)$ were younger consumers aged between 18-26 years-old (comprised of students and early career employees). The focus of the future study may be emphasized on older consumers, since they may have more purchasing power and tend to be much advanced in their family life cycle stage (i.e., more likely to be married and have children). This combination of personal condition may increase or inhibit impulsiveness, and thus may be interesting to study. Another variable that may be added when studying older consumers, is perhaps self-regulation. Verplanken and Sato (2011) suggested that past studies have linked impulse buying with self-regulation (i.e., ability to control one's thoughts, feelings, and behavior) and that it makes sense to apply self-regulation perspective on impulse buying.

Another limitation is in terms of geographic location of the respondents. Despite using online survey, the responses were mainly from the Jakarta area. In future studies, perhaps geographic location can be focused on other major cities in Indonesia, such as Surabaya, Medan, Bandung, and Makassar, which are often cited as major cities with most online buyers in Indonesia (Bachdar 2018). This would add comparative data that can confirm or contradict the results from this study.

\section{REFERENCES}

Akram U, Hui P, Kaleem KM, Tanveer Y, Mehmood K, Ahmad W. 2018. How website quality affects online impulse buying. Asia Pacific Journal of Marketing and Logistics 30(1): 235-256. https:// doi.org/10.1108/APJML-04-2017-0073.

Akram U, Hui P, Khan MK, Saduzai SK, Akram Z, Bhati MH. 2017. The plight of humanity: Online impulse shopping in China. Human Systems Management 36(1): 73-90. https://doi. org/10.3233/HSM-171768.

Bachdar S. 2018. Lima kota Indonesia dengan jumlah pembelanja online terbesar. Marketeers. http:// marketeers.com/lima-kota-indonesia-denganjumlah-pembelanja-online-terbesar/ [January 26, 2019].

Badgaiyan AJ, Verma A. 2015. Does urge to buy impulsively differ from impulsive buying 
behaviour? Assessing the impact of situational factors. Journal of Retailing and Consumer Services 22: 145-157. https://doi.org/10.1016/j. jretconser.2014.10.002.

Bagozzi RP, Yi Y. 1988. On the evaluation of structural equation models. Journal of the Academy of Marketing Science 16(1): 74-94. https://doi. org/10.1007/BF02723327.

Beaujean AA. 2014. Latent Variable Modeling Using R: A Step-by-Step Guide. New York: Routledge.

Bellini S, Cardinali MG, Grandi B. 2017. A structural equation model of impulse buying behaviour in grocery retailing. Journal of Retailing and Consumer Services 36: 164-171. https://doi. org/10.1016/j.jretconser.2017.02.001.

Chen CC, Yao JY. 2018. What drives impulse buying behaviors in a mobile auction? The perspective of the Stimulus-Organism-Response model. Telematics and Informatics 35(5): 1249-1262. https://doi.org/10.1016/j.tele.2018.02.007.

Chen JV, Su BC, Widjaja AE. 2016. Facebook C2C social commerce: A study of online impulse buying. Decision Support Systems 83: 57-69. https://doi.org/10.1016/j.dss.2015.12.008.

Dawson S, Kim M. 2009. External and internal trigger cues of impulse buying online. Direct Marketing 3(1): 20-34. https://doi. org/10.1108/17505930910945714.

Eriksson N, Rosenbröijer CJ, Fagerstrøm A. 2017. The relationship between young consumers' decisionmaking styles and propensity to shop clothing online with a smartphone. Procedia Computer Science 121: 519-524. https://doi.org/10.1016/j. procs.2017.11.069.

Euromonitor International. 2018. Internet Retailing in Indonesia. https://www.euromonitor.com/ internet-retailing-in-indonesia/report[January 26, 2019].

Euromonitor International. 2019. Retailing in Indonesiaanalysis. https://www.euromonitor.com/internetretailing-in-indonesia/report[January 26, 2019].

Floh A, Madlberger M. 2013. The role of atmospheric cues in online impulse-buying behavior. Electronic Commerce Research and Applications 12(6): 425-439. https://doi.org/10.1016/j. elerap.2013.06.001.

Fornell C, Larcker DF. 1981. Evaluating structural equation models with unobservable variables and measurement error. Journal of Marketing Research 18(1): 39-50. https://doi. org/10.2307/3151312.
Hair JF, Black WC, Babin BJ, Anderson RE. 2014. Multivariate Data Analysis. Ediburgh: Pearson Education Limited.

Kemp S, Moey S. 2019. Digital 2019 Spotlight: E-commerce in Indonesia. https://datareportal. com/reports/digital-2019-ecommerce-inindonesia[January 26, 2019].

Leong LY, Jaafar NI, Ainin S. 2018. The effects of Facebook browsing and usage intensity on impulse purchase in f-commerce. Computers in Human Behavior 78: 160-173. https://doi. org/10.1016/j.chb.2017.09.033.

Lertwannawit A, Mandhachitara R. 2012. Interpersonal effects on fashion consciousness and status consumption moderated by materialism in metropolitan men. Journal of Business Research 65(10), 1408-1416. https://doi.org/10.1016/j. jbusres.2011.10.006.

Liao SL, Shen YC, Chu CH. 2009. The effects of sales promotion strategy, product appeal and consumer traits on reminder impulse buying behaviour. International Journal of Consumer Studies 33(3): 274-284. https://doi.org/10.1111/j.14706431.2009.00770.x.

Liu Y, Li H, Hu F. 2013. Website attributes in urging online impulse purchase: An empirical investigation on consumer perceptions. Decision Support Systems 55(3): 829-837. https://doi. org/10.1016/j.dss.2013.04.001.

Lo LYS, Lin SW, Hsu LY. 2016. Motivation for online impulse buying: A two-factor theory perspective. International Journal of Information Management 36(5): 759-772. https://doi. org/10.1016/j.ijinfomgt.2016.04.012.

Loiacono E, Watson R, Goodhue D. 2007. WebQual: An instrument for consumer evaluation of web sites. International Journal of Electronic Commerce 11(3): 51-87. https://doi.org/10.2753/JEC10864415110302.

Madhavaram S R, Laverie DA. 2004. Exploring Impulse Purchasing on the Internet Exploring Impulse Purchasing on the Internet. Association for consumer research 31(31): 59-66.

Mittal S, Sondhi N, Chawla D. 2018. Process of impulse buying: A qualitative exploration. Global Business Review 19(1): 131-146. https:// doi.org/10.1177/0972150917713368.

Nunnally JC. 1978. Psychometric theory. McGrawHill.

O'Cass A, Lee WJ, Siahtiri V. 2013. Can Islam and status consumption live together in the house of 
fashion clothing? Journal of Fashion Marketing and Management 17(4): 440-459.

Parboteeah DV, Valacich JS, Wells JD. 2009. The influence of website characteristics on a consumer's urge to buy impulsively. Information Systems Research 20(1): 60-78.

Park EJ, Kim EY, Forney JC. 2006. A structural model of fashion-oriented impulse buying behavior. Journal of Fashion Marketing and Management, 10(4), 433-446.

Park EJ, Kim EY, Funches VM, Foxx W. 2012. Apparel product attributes, web browsing, and e-impulse buying on shopping websites. Journal of Business Research 65(11): 1583-1589.

Prihantoro WP. Satria A, Hartoyo H. (2018). The determinant factors of behavior in m-commerce application usage for online purchasing. Indonesian Journal of Business and Entrepreneurship 4(2).

$\mathrm{R}$ Core Team. 2013. $R$ : A language and environment for statistical computing. Vienna: R Foundation for Statistical Computing.

Rook DW. 1987. The buying impulse. Journal of Consumer Research 14(2): 189-199. https://doi. org/10.1086/209105.

Rook D W, Fisher RJ. 1995. Normative influences on impulsive buying behavior. Journal of Consumer Research 22(3): 305-313. https://doi. org/10.1086/209452.

Roseel Y. 2012. lavaan: An R Package for Structural Equation Modeling. Journal of Statistical
Software 48(2): 1-36. https://doi.org/10.18637/ jss.v048.i02.

Solomon MR, Marshall GW, Stuart EW. 2018. Marketing Real People Real Choices (9th ed.). Prentice Hall: Pearson Education Limited.

Sproles G, Kendall E. 1986. The methodology of profiling consumers' decision-making styles. The American Council on Consumer Interests 20(2): 267-279. https://doi.org/10.1111/j.17456606.1986.tb00382.x.

Sundström M, Hjelm-Lidholm S, Radon A. 2019. Clicking the boredom away - Exploring impulse fashion buying behavior online. Journal of Retailing and Consumer Services 47: 150-156. https://doi.org/10.1016/j.jretconser.2018.11.006.

Turkyilmaz CA, Erdem S, Uslu A. 2015. The effects of personality traits and website quality on online impulse buying. Procedia - Social and Behavioral Sciences 175: 98-105. https://doi. org/10.1016/j.sbspro.2015.01.1179.

Verplanken B, Sato A. 2011. The psychology of impulse buying: An integrative self-regulation approach. Journal of Consumer Policy 34(2): 197-210. https://doi.org/10.1007/s10603-011-9158-5.

Wells J, Parboteeah V, Valacich J. 2011. Online impulse buying: Understanding the interplay between consumer impulsiveness and website quality. Journal of the Association for Information Systems 12(1): 32-56. https://doi. org/10.17705/1jais.00254. 